Boletín de la Sociedad Geológica Mexicana

VOLUMEN 65, NÚM. 3, 2013, P. 631-643

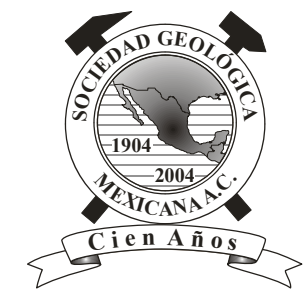

\title{
Eocene Bursera (Burseraceaea) in La Carroza Formation, Mexico: a dry tropical flora member
}

\author{
Laura Calvillo-Canadell1,*, Oris J. Rodríguez-Reyes², Rosalinda Medina-Lemos ${ }^{3}$, \\ Sergio R.S. Cevallos-Ferriz ${ }^{1}$
}

\author{
${ }^{1}$ Departamento de Paleontología, Instituto de Geología, Universidad Nacional Autónoma de México, Ciudad Universitaria, Circuito \\ de la Investigación Científica, Del. Coyoacán, 04510 México D.F., Mexico. \\ ${ }^{2}$ Department of Earth Sciences, Royal Holloway, University of London. \\ ${ }^{3}$ Departamento de Biología, Instituto de Biología, Universidad Nacional Autónoma de México, Ciudad Universitaria, Circuito \\ Exterior, Del. Coyoacán, 04510 México D.F., México. \\ *1ccanadell@me.com
}

\begin{abstract}
History of plant diversity in Mexico might be sought in detailed descriptions and comparisons of fossil taxa. Fossil plants allow the recognition of plant communities and their history, especially if they include key elements. In Mexico, Bursera is correlated with dry tropical habitats, and its presence in the fossil record certainly helps to trace the history of both the taxon and the habitat. Eocene material from the La Carroza Formation, La Popa basin, in Nuevo León, Mexico contains a diverse leaf assemblage among which certain leaves resemble two morphotypes, both members of Bursera. A brief description of the leaf architecture of Burseraceae is presented in order to unify criteria and establish comparative parameters that allow identification of fossil leaflet compressions and impressions. Burseraceae has variable leaf architecture, and a single character can change in a single leaf and/or leaflet. For example, the characteristic brochidodromous condition of the family may change to craspedodromous, semi-craspedodromous or even eucamptodromous, in a single leaf. Both Eocene species that are recognized here suggest that the sections Bursera and Bullockia, were differentiated around Middle Eocene; however, previous studies suggest an earlier differentiation of these sections. The two new fossil species in La Popa basin support the presence of members of the extant dry tropical forest in northwestern Mexico, but not necessarily the presence of a dry community. This community developed at a time of geologic/physiographic changes in the area, promoting drought and the establishment of a dry flora.
\end{abstract}

Keywords: Burseraceae leaves; Eocene; La Carroza Formation; leaf architecture; Nuevo León, Mexico.

\section{Resumen}

La historia de la diversidad vegetal en México podría ser buscada en descripciones detalladas y comparaciones de los taxa fósiles. Las plantas fósiles permiten el reconocimiento de las comunidades vegetales y su historia, sobre todo si incluyen elementos clave. En México, Bursera se correlaciona con hábitats tropicales secos, y su presencia en el registro fósil sin duda ayuda a trazar la historia tanto del taxón como del hábitat. Material del Eoceno de la Formación La Carroza, cuenca La Popa, en Nuevo León, México, contiene un conjunto diverso de hojas entre las cuales algunas se describen como dos morfotipos, ambos miembros de Bursera. Una breve descripción de la arquitectura de la hoja de Burseraceae se presenta para unificar criterios y establecer parámetros de comparación que permiten la identificación de las compresiones/impresiones fósiles. Burseraceae tiene arquitectura foliar variable, y un carácter particular puede cambiar en una sola hoja y/o foliolo. Por ejemplo, la condición broquidódroma, característica de la familia, puede cambiar a craspedódroma, semi-craspedódroma o incluso eucamptódroma en una sola hoja. Las dos especies del Eoceno que se reconocen aqui sugieren que las secciones Bursera y Bullockia, se diferenciaron en el Eoceno medio, aunque estudios anteriores sugieren 
su diferenciación anterior. Las dos nuevas especies fósiles de La Popa apoyan la presencia de miembros de la selva tropical seca en ese momento en el noroeste de México, pero no necesariamente la presencia de una comunidad del trópico seco. Esta comunidad fósil se desarrolla en un momento de cambios geológicos/fisiográficos de la zona, mismos que promovieron la sequía y el establecimiento de una flora que sugiere sequía.

Palabras clave: Hojas de Burseraceae; Eoceno, Formación La Carroza, arquitectura foliar, Nuevo León, México.

\section{Introduction}

The increase in biodiversity in low latitude North America (Mexico) is far from being understood, and data from many fields (botany, geology, pedology, tectonics, geography, etc.) are necessary to understand the factors involved in the evolution of the biota that today contains a variety of communities (e.g., Becerra, 2005; Schrire et al., 2005a, 2005b; Cevallos-Ferriz and González-Torres, 2006; Antonelli et al., 2009; Antonelli and Sanmartín, 2011). Detailed comparison of fossil and extant plants produces taxonomic and ecological data that have proved useful in phylogenetic analyses. These data may be used to generate hypotheses on the evolution of past communities.

The geography of Mexico throughout its geologic history has favored the establishment of tropical communities, hypothesis supported by the plant fossil record, especially through Cretaceous-Cenozoic time (e.g., Graham and Dilcher, 1995; Gentry, 1995; Graham, 1999, 2010, 2011; Martínez-Yrízar et al., 2000; Burnham and Johnson, 2004; Pennington et al., 2004; Calvillo-Canadell and CevallosFerriz, 2005; Martínez-Cabrera and Cevallos-Ferriz, 2008). However, it is difficult to tell based only on floristic lists if a certain paleoflora represents a dry tropical, evergreen, or some sort of intermediate forest (Mooney et al., 1995; Pennington et al., 2006a, 2006b). Characterization of these forests is based on floristic elements and climatic/ environmental data gathered from physiognomic and ecological analyses of extant floras (Castañeda-Posadas and Cevallos-Ferriz, 2007; Estrada-Ruiz et al., 2008; MartínezCabrera and Cevallos-Ferriz, 2008).

Description of fossil plants in recent years has allowed the recognition of evergreen and semi-evergreen forests, e.g., those collected in the Cretaceous Olmos and Cerro del Pueblo formations from Coahuila that may represent paratropical forests (Estrada-Ruiz et al., 2008), and the Miocene Panotla flora of Tlaxcala and the Chajul flora of Chiapas reconstructed as evergreen (selva alta) tropical forests (Castañeda-Posadas and Cevallos-Ferriz, 2007; Peralta-Medina, 2009; Calvillo-Canadell et al., 2010). Other fossil floras, however, have been described as dry tropical forests, e.g., the Oligocene Los Ahuehuetes flora of the Coatzingo Formation, Puebla, which has been compared to a chaparral or a low-elevation tropical forest (RamírezGarduño and Cevallos-Ferriz, 2000; Calvillo-Canadell and Cevallos-Ferriz, 2007). The flora of the Miocene El Cien from Baja California Sur suggests it was a low-elevation (dry) tropical forest, but the wood ecological analysis suggests it was an evergreen forest (Martínez-Cabrera and Cevallos-Ferriz, 2008). Similar floras have been described elsewhere (Graham and Dilcher, 1995; Pennington et al., 2000; Burnham and Johnson, 2004), but unfortunately little has been resolved regarding the origin and expansion of the dry tropical communities (Pennington et al., 2000, 2004, 2006a, 2006b, 2006c, 2009; Becerra, 2003, 2005; Schrire et al., 2005a, 2005b, 2009).

It has been suggested that dry tropical floras represent the most widespread tropical communities (Miranda and Hernández-X., 1963; Murphy and Lugo, 1986; Gentry, 1995; Mooney et al., 1995; Trejo, 1996; Becerra, 2003, 2005; Schrire et al., 2005a, 2005b, 2009; Pennington et al., 2006a, 2006b). Furthermore, these dry communities may be found beyond the tropical zones, especially if they occupy low altitudes in ordinarily humid regions, or less humid but higher elevation sites, and even in places with dryer conditions (e.g., central Mexico or El Cerrado, Brazil) (Rundel and Boonpragob, 1995; Trejo, 1996; Cerros-Tlatilpa and Espejo-Serna, 1998; Martínez-Yrízar et al., 2000; Cervantes-Duarte et al., 2001; Camacho-Rico et al., 2006).

If defining these communities in today's vegetation is complicated, recognizing them in the past is no easier since all the physiographic and ecological components vary through time. However, information from the fossil record provides direct evidence critical to hypotheses on the origin of the dry tropical forests of the world. This approach will allow the assessment of hypotheses based on the phylogenetic community structure or the neutral ecological theory of extant floras (Pennington et al., 2000, 2004, 2006a, 2006b; Becerra, 2003, 2005; Schrire et al., 2005a, 2005b, 2009; Antonelli et al., 2009; Antonelli and Sanmartín, 2011; Bartish et al., 2011, De Nova et al., 2012).

A new Eocene fossil locality in the Carroza Formation with fruits and dispersed leaves and leaflets in La Popa basin, Nuevo León (Fig. 1), contains a suite of taxa suggesting the presence of a dry tropical forest (Calvillo-Canadell and Cevallos-Ferriz, 2002, 2005, 2007). During the Eocene, this region had a geographic location that would support the presence of humid tropical vegetation. However, leaf and leaflet morphological characters of the fossil flora (e.g., microphyllous, entire margins, some with toothed margins) suggest that this was part of the vegetation of a dry 


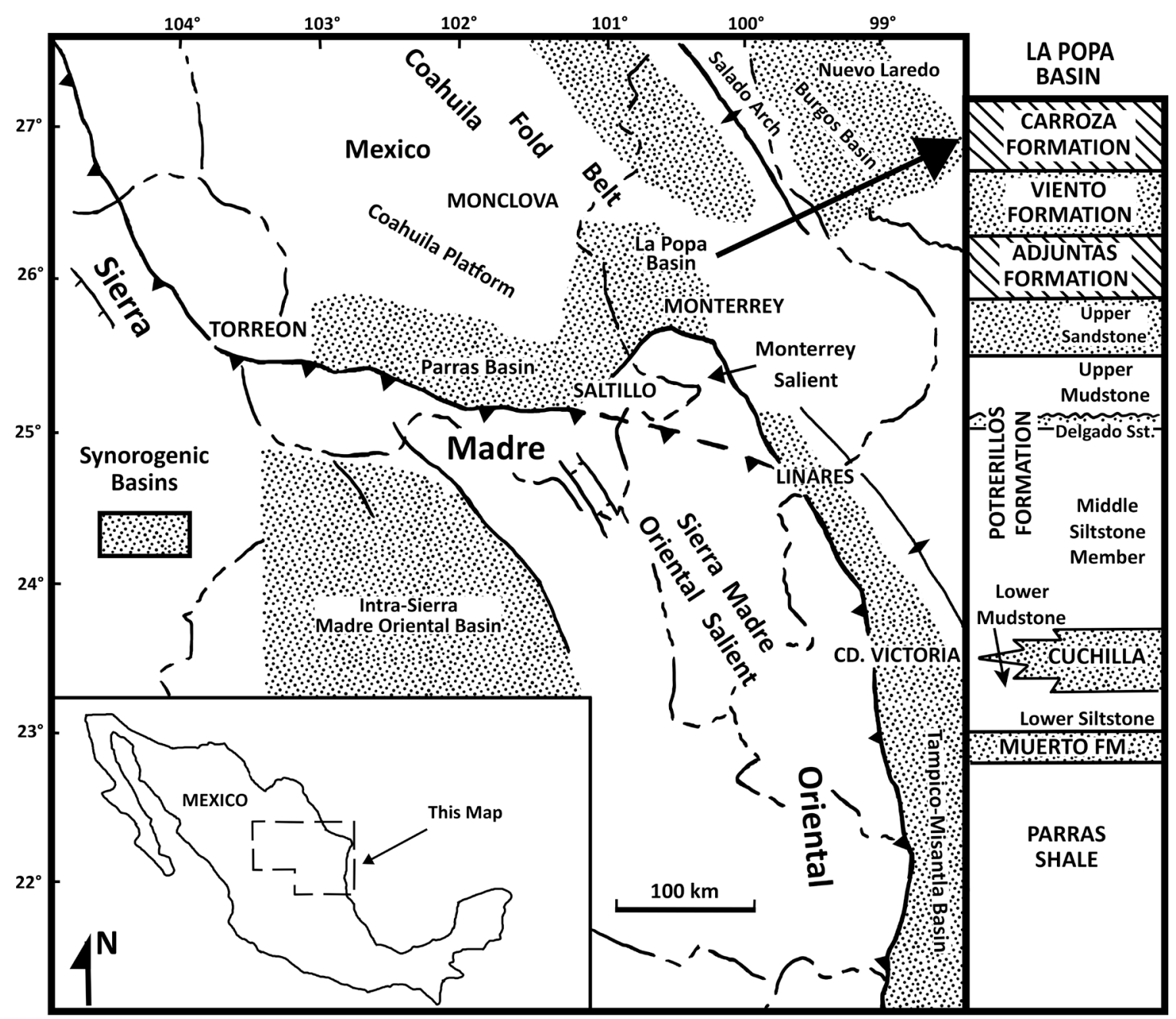

Figure 1. Geographic location of fossil locality, and stratigraphic position of leaf bearing sediments

region (McBride et al., 1974; Givinish, 1979; Wendt, 1993; Soeegard et al., 2003; Calvillo-Canadell and CevallosFerriz, 2005; Andrie et al., 2010). The composition of this flora can also be explained by suggesting the presence of a predominantly humid tropical flora with some dry elements. Paleopedological analyses of soils along the geologic sequence containing the flora further suggest that at the time of deposition the region was arid (McBride et al., 1974; Givinish, 1979; Soeegard et al., 2003; Calvillo-Canadell and Cevallos-Ferriz, 2005; Andrie et al., 2010). Although the age of this plant locality is not well established yet, its dry components suggest that it may correspond to a period during the middle or late Eocene. Contemporaneous with this flora is the expansion of aridity in North America during the mid-Paleogene transitional interval (Scotese, 2002; Willis and McElwain, 2002), as suggested by the dry tropical Green River flora of Colorado and Utah (Graham, 1999). Paleogene dry areas and vegetation may develop from seasonal conditions, more locally due to the edaphic, slope or topographic situations (McBride et al., 1974; Soeegard et al., 2003; Schrire et al., 2005a, 2005b; Cevallos-Ferriz and González-Torres, 2006; Andrie et al., 2010; Antonelli et al., 2009; Antonelli and Sanmartín, 2011).

The current paper adds to the understanding of paleobiodiversity in northeastern Mexico, based on dispersed leaflets that are preserved in La Popa basin of La Carroza Formation, Nuevo León (Fig. 1). Based on detailed comparison of fossil and extant plant material, we support the presence of two new species of Bursera, an excellent indicator of dry tropical forest in Mexico. These new taxa help to support a hypothesis that explains the methods of dispersal and routes through which taxa of this type of community became important in the low latitude vegetation of North America.

\section{Materials and methods}

Leaves and leaflets preserved as impression/compression fossils in La Carroza Formation have been collected near 
San Francisco ranch, the closest inhabited place to the plant localities, which is $c a .4 \mathrm{~km}$ east of San José de La Popa, Nuevo León, at $26^{\circ} 00^{\prime} 00^{\prime \prime}-27^{\circ} 00^{\prime} 00^{\prime \prime} \mathrm{N}$ and $100^{\circ} 30^{\prime} 00^{\prime \prime}$ $-101^{\circ} 00^{\prime} 00^{\prime \prime} \mathrm{W}$. This geologic unit represents the youngest portion of the Difunta Group (Late Cretaceous to middle Eocene) in the Parras, La Popa and southern Sabinas basins (Fig. 1; Perrilliat and Vega, 2003). La Carroza Formation itself has not been dated, but physical stratigraphy and its relation with the underlying Viento Formation of early Eocene age, based on the presence of Ostrea (Turkostrea) strictiplicata Raulin and Delbos, O. (T.) duvali Gardner, $O$. (T.) escondida Perrilliat and Vega and O. (?) popaensis Perrilliat and Vega (Perrilliat and Vega, 2003), suggest a middle Eocene age. Recent radiometric studies on a tuff intercalated among the paleosoils of the section containing the plant material suggest that the sediments might be of Paleocene age; but a second date is recommended before accepting this proposal (Lawton and Buck, pers. comm., 2007). The studied section consists of bioturbated siltstone and fine to medium-grained, lenticular or cross stratified sandstone deposited in alluvial environments, as suggested by the presence of Pachychilus lawtoni Perrilliat, Vega, Espinosa and Naranjo-García (Perrilliat et al., 2008).

A large number of leaves/leaflets deposited in the "Colección Nacional de Paleontología" (National Paleontological Collection ), Instituto de Geología, Universidad Nacional Autónoma de México (UNAM), were analyzed to document the presence of two distinct Bursera-like plants based on their leaf architectural variability. Specimens were examined with an Olympus SZH stereomicroscope (equipped with a camera lúcida), a Zeiss Stemi DV4, a Zeiss Stemi 2000-C and an Olympus BH-2 with transmitted light. Photographs were taken with an Olympus DP11 camera with polarizing filters and a Canon Power Shot ${ }^{\circledR}$ 640. Macrophotography used a Sony Cyber-Shot ${ }^{\circledR}$ DSC-F828 camera. Image processing used Axio Vision ${ }^{\circledR} 4.6$ or Adobe Photoshop ${ }^{\circledR}$ CS4. A comparative search based on morphological characters was performed using the Meka (Duncan and Meacham, 1986) and Delta databases (Watson and Dallwitz, 1992). Extant materials from the Herbario Nacional de México (MEXU) at the Instituto de Biología, UNAM, and photographs of herbarium specimens available in high resolution formats from Aluka (www.aluka.org) and Royal Botanic Gardens of Kew (apps. kew.org/herbcat/navigator.do) were studied and compared until the most convincing determinations were obtained. A literature search on extant and fossil records of Bursera was carried out aided by consulting the Paleobiology Database (Alroy et al., 2004). Description of the leaf types is based on the Manual of Leaf Architecture (Ellis et al., 2009) and consulting experts on these topics, such as Dr. M. MartínezMillán (Cornell University), Dr. J. Rzedowski (Instituto de Ecología, A.C., Pátzcuaro), and Dr. D. C. Daly (The New York Botanical Garden).

\section{Systematic descriptions}

\author{
Family: Burseraceae \\ Genus: Bursera Jacq. ex L. \\ Section: Bursera
}

Bursera popensis Calvillo-Canadell, Rodríguez-Reyes, Medina-Lemos, and Cevallos-Ferriz

(Fig. 2.1-2.2).

Holotype: IGL-01345pb

Repository: "Colección Nacional de Paleontología" (National Paleontological Collection), Instituto de Geología, UNAM.

Locality: Rancho San Francisco, close to the town of San José de La Popa, Nuevo León, Mexico; between $26^{\circ}$ and $26^{\circ} 10^{\prime} \mathrm{N}$ and $100^{\circ} 40^{\prime}$ and $100^{\circ} 50^{\prime} \mathrm{W}$, or $\mathrm{x}=358,296$; $\mathrm{y}=2,885,706$; UTM 14 zone; datum WGS84.

Stratigraphy: La Carroza Formation, Difunta Group.

Age: middle Eocene

Etymology: The specific epithet refers to the San José de La Popa area, where the fossil material was collected.

Diagnosis: Leaflet narrowly elliptic-oblong, lamina asymmetric, base cuneate-convex; margin serrate except in proximal zone, teeth apex cunonioid. First order venation pinnate, midvein well-developed. Secondary veins semicraspedodromous and cladodromous in distal part. Weak inter-secondary veins present. Third-order venation random reticulate. Fourth-order venation freely ramified in unequal dendritic form. Areoles well-developed. Veinlets ramified.

Description: The material consists of four leaflets with narrow elliptic - oblong, asymmetric lamina of the nanophyll type, $4.00 \mathrm{~mm}$ wide and $1.7 \mathrm{~mm}$ long, with length/ width ratio of $3: 1$ (Fig. 2.1). Its petiolule is not preserved and the margin is serrate except near the basal one-third (Fig. 2.1). The apex appears to be straight with an acute angle of $40^{\circ}$. The base is cuneate-convex (Fig. 2.1) with an acute angle of $35^{\circ}$. Primary venation is pinnate with well-developed midvein (Fig. 2.1). Second-order venation is semi-craspedodromous in the basal half of the lamina (Fig. 2.1 [lower arrow]), and cladodromous in the distal portion (Fig. 2.1), with irregular spacing between major secondaries (Fig. 2.1) that form an acute angle $\left(20^{\circ}-40^{\circ}\right)$ with the midvein. This angle tends to decrease slightly toward the proximal zone (Fig. 2.1) and major secondary veins attached in excurrent form to the midvein (Fig. 2.1). Weak inter-secondary veins run parallel to major secondaries; their length is less than $50 \%$ of the subjacent secondary vein and have a ramified distal course (Fig. 2.1). The third-order venation has a random reticulate pattern (Fig. 2.1, upper arrow) while the fourth order venation ramifies freely in an unequal dendritic form (Fig. 2.1), and forms the free ending veinlets that ramify two or more times (Fig. 2.1). Three to five sided areoles form well-developed polygons (Fig. 2.1). The marginal ultimate venation is looped (Fig. 2.1). Two orders of teeth with regular spacing 
have an angular sinus shape, with a straight - convex distal flank and convex proximal flank (Fig. 2.2 [arrow]). The cunonioid tooth apex is simple with no distinctive tissue or structure. Tertiary veins go directly to the tooth, lacking distinction of principal and/or accessory veins (Fig. 2.2). There are four teeth per centimeter.

\section{Section: Bullockia}

\section{Bursera ezequielii Calvillo-Canadell, Rodríguez-Reyes, Medina-Lemos, and Cevallos-Ferriz}

(Fig. 2.3-2.6)

\section{Holotype: IGM-PB 1356}

Repository: "Colección Nacional de Paleontología" (National Paleontological Collection), Instituto de Geología, UNAM.

Locality: Rancho San Francisco, close to the town of San José de La Popa, Nuevo León, Mexico; between $26^{\circ}$ and $26^{\circ} 10^{\prime} \mathrm{N}$ and $100^{\circ} 40^{\prime}$ and $100^{\circ} 50^{\prime} \mathrm{W}$, or $\mathrm{x}=358,296$; $\mathrm{y}=2,885,706$; UTM 14 zone; datum WGS84.

Stratigraphy: La Carroza Formation, Difunta Group. Age: middle Eocene

Etymology: The specific epithet refers to Mr. Ezequiel Cerda, who collected fossil plant material in the La Popa region during the last decade.

Diagnosis: Leaflets elliptic-ovate, sessile. Rachis finely winged. Leaf margin crenate - serrate, teeth apex cunonioid; lamina symmetrical. First order venation pinnate; well developed midvein. Secondary venation mostly eucamptodromous, cladodromous near the base; weak intersecondary veins. Third-order venation random reticulate. Fourth order venation dichotomous. Areoles well developed; ramified veinlets. Marginal ultimate venation looped.

Description: The material consists of one incomplete compound leaf with one sessile leaflet attached to the finely winged rachis (Fig. 2.3), and three isolated leaflets. Opposite to the attached leaflet a scar indicates the position of a second leaflet (Fig. 2.3). The rachis is $2.5 \mathrm{~cm}$ long and $0.1 \mathrm{~mm}$ wide. Three other fragmented and isolated leaflets are dispersed in other samples (Fig. 2.4-2.5). All of them are elliptic - ovate, nanophyll type, 1.0 to $1.3 \mathrm{~cm}$ long and 0.4 to $0.5 \mathrm{~mm}$ wide and appear to be symmetrical (Fig. 2.3-2.5). The base and the apex are incomplete, but in one of the specimens it is possible to infer a probable convex base (Fig. 2.3-2.4) and in other leaflet the apex tends to be straight (Fig. 2.3-2.4). The leaflet margin is crenate near its base (Fig. 2.4), and serrate towards the apex (Fig. 2.5). There is a well developed midvein (Fig. 2.4, lower arrow). The major venation is pinnate. Second-order venation is eucamptodromous in the proximal $75 \%$ of the leaflet and cladodromous near the base (Fig. 2.3, 2.5), with irregular spacing between major secondaries that form an acute angle $\left(38^{\circ}-50^{\circ}\right)$ with the midvein. The midvein thins smoothly decreasing in diameter toward the apex. Major secondaries have an excurrent pattern (Fig. 2.4, 2.5). Inter-secondary veins are weak and run parallel to major secondaries; some of them have a length more than $50 \%$ of the subjacent secondary vein and a ramified distal course. Third-order venation has a random-reticulate pattern while the quaternary order venation is freely ramified with dendritic branching (Fig. 2.4, upper arrow), and forms the freely ending veinlets that ramify one or two times (Fig. 2.5). Areoles form welldeveloped polygons of three to five sides (Fig. 2.5-2.6). The marginal ultimate venation is looped. There are two orders of convex-convex teeth with regular spacing and an angular sinus (Fig. 2.5, upper arrow). The tooth apex is simple with no thickened areas or glands. Tertiary veins go directly to the tooth, lacking accessory veins. There are four teeth per centimeter (Fig. 2.5).

\section{Discussion}

The relatively small amount of specimens collected so far is not a limitation for systematic work, as the characters preserved provide important taxonomic information. In this case, leaf architecture strongly backs-up the identification and discussion of the fossil material, as it relates the new leaf types with Sapindales, based on the presence of cunonioid teeth, pinnate venation and semicraspedodromous secondary venation (Hickey and Wolfe, 1975; Martínez-Millán and Cevallos-Ferriz, 2005; Daly et al., 2011). Among the families in the order, Anacardiaceae and Burseraceae are similar to the fossil leaves based on the tendency of veins to form arcs, the irregularly distributed of convex/convex and straight/convex teeth, with a single vein entering the sinus, and reticulate third order venation (Martínez-Millán and Cevallos-Ferriz, 2005; Daly et al., 2011). Other families in the order either have entire leaves, or their secondary veins do not form or tend to form arcs, as Meliaceae, Simaroubaceae or Rutaceae do. The next discussion is based mainly on our own observations, since detailed leaf architecture observations for members of Anacardiaceae and Burseraceae are to be reviewed in order to unify morphological criteria for their description (Solereder, 1908; Metcalfe and Chalk, 1950; Hickey and Wolfe, 1975; Andrés-Hernández, 1977, 2001; Rzedowski and Kruse, 1979; Daly, 1993, 1997; Becerra and Venable, 1999). Nonetheless, more recent descriptions are important to interpret the new fossil material (Martínez-Millán and Cevallos-Ferriz, 2005; Daly et al., 2011).

The new material from La Popa, Nuevo León resembles some species of Pseudosmodingium (Anacardiaceae), especially P. andrieuxii (Baill.) Engl. (Fig. 3.15-3.17; Martínez-Millán and Cevallos-Ferriz, 2005). Detailed comparison shows that in Pseudosmodingium the distance between sinuses is irregular, the sinus shape may be angular and rounded even in the same leaflet, the teeth shape is straight/straight, the secondary veins tend to enter the teeth and appear to be craspedodromous, and areoles are not well 


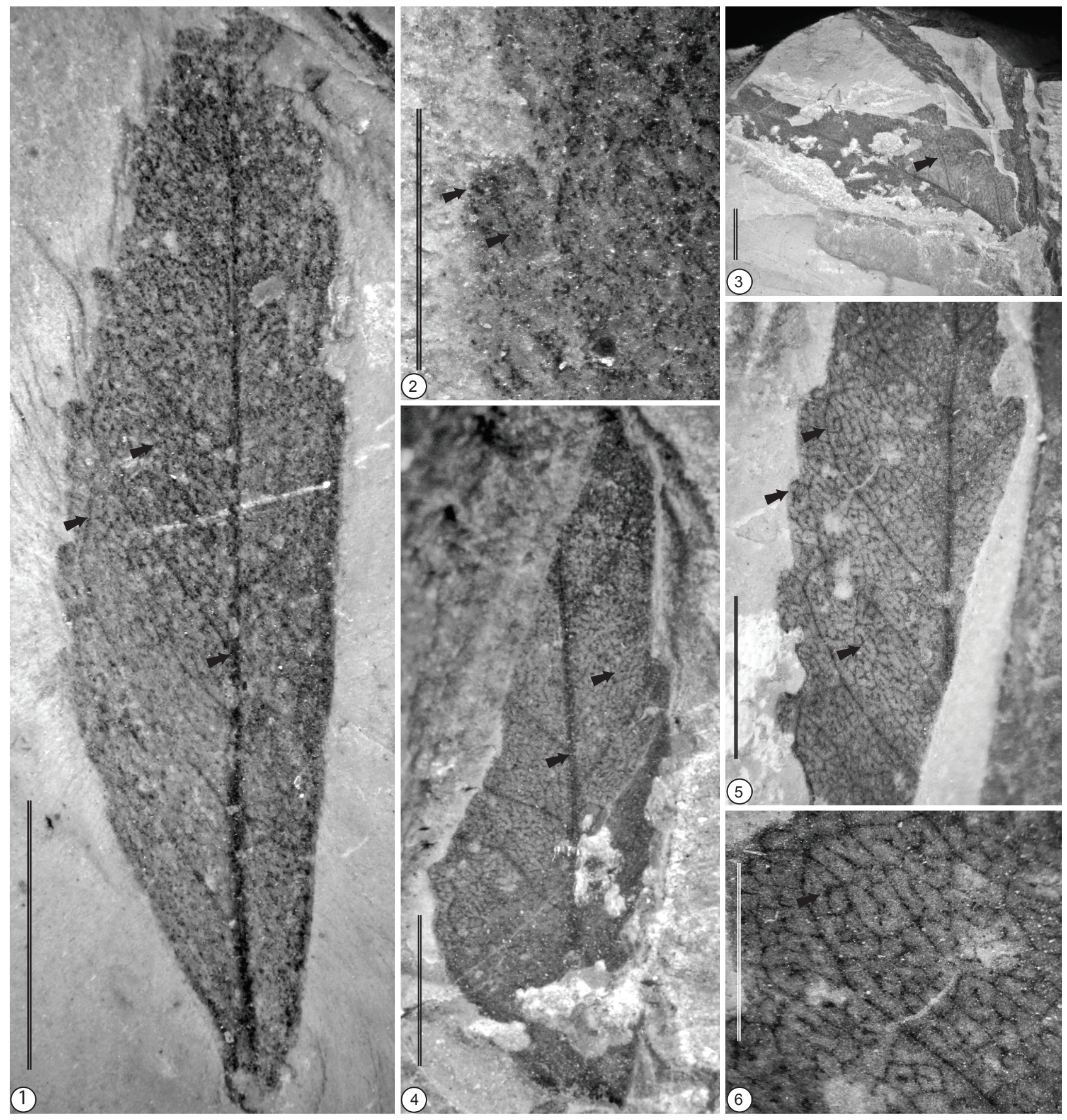

Fig. 2, 1-2. Bursera popensis Calvillo-Canadell et al.; 3-6. Bursera ezequieli Calvillo-Canadell et al. 1. General view of asymmetric leaflet, entire and serrate margin, semi-craspedodromous (lower arrow) and cladodromousvenation, third order venation (upper arrow). Scale $=0.4 \mathrm{~mm}$. 2 . Tooth (arrow) with angular sinus shape. Scale $=0.1 \mathrm{~mm}$. 6. Cuneate-convex asymmetrical base. Scale $=0.1 \mathrm{~mm}$. 3. Leaflet attached to winged rachis. Scale $=0.4 \mathrm{~mm}$. 4. Leaflet with elliptic-ovate lamina, convex base, pinnate first order venation (lower arrow) and third order venation (upper arrow). Scale $=0.3 \mathrm{~mm}$. 5. Incomplete lamina with basal $75 \%$ having eucamptodromous venation, tertiary veins forming random reticulate pattern, areoles, with freely ending veinlets and two orders of teeth (upper arrow). Scale $=0.1 \mathrm{~mm}$. 6. Areoles with freely ending veinlets (dichotomous). Scale $=0.1 \mathrm{~mm}$.

developed, thus differing from the new Bursera species. Furthermore, Pseudosmodingium seems to have more teeth on the wider side of the leaflet.

Comparison with Burseraceae strongly suggests a morphological affinity of the fossil material with extant taxa of this family. Sections or group definitions within this family are not recognized based on leaf architecture (Daly et al., 2011), suggesting that the use of leaf architectural patterns in taxonomic discussion must be done with great care. For example, while entire margins are common in Commiphora, Protium, Canarium, Tetragastris and Dacryodes, these genera also have species with serrate/ toothed or crenate margins. In contrast, the entire margin in Bursera is less frequent, though present in B. simaruba 


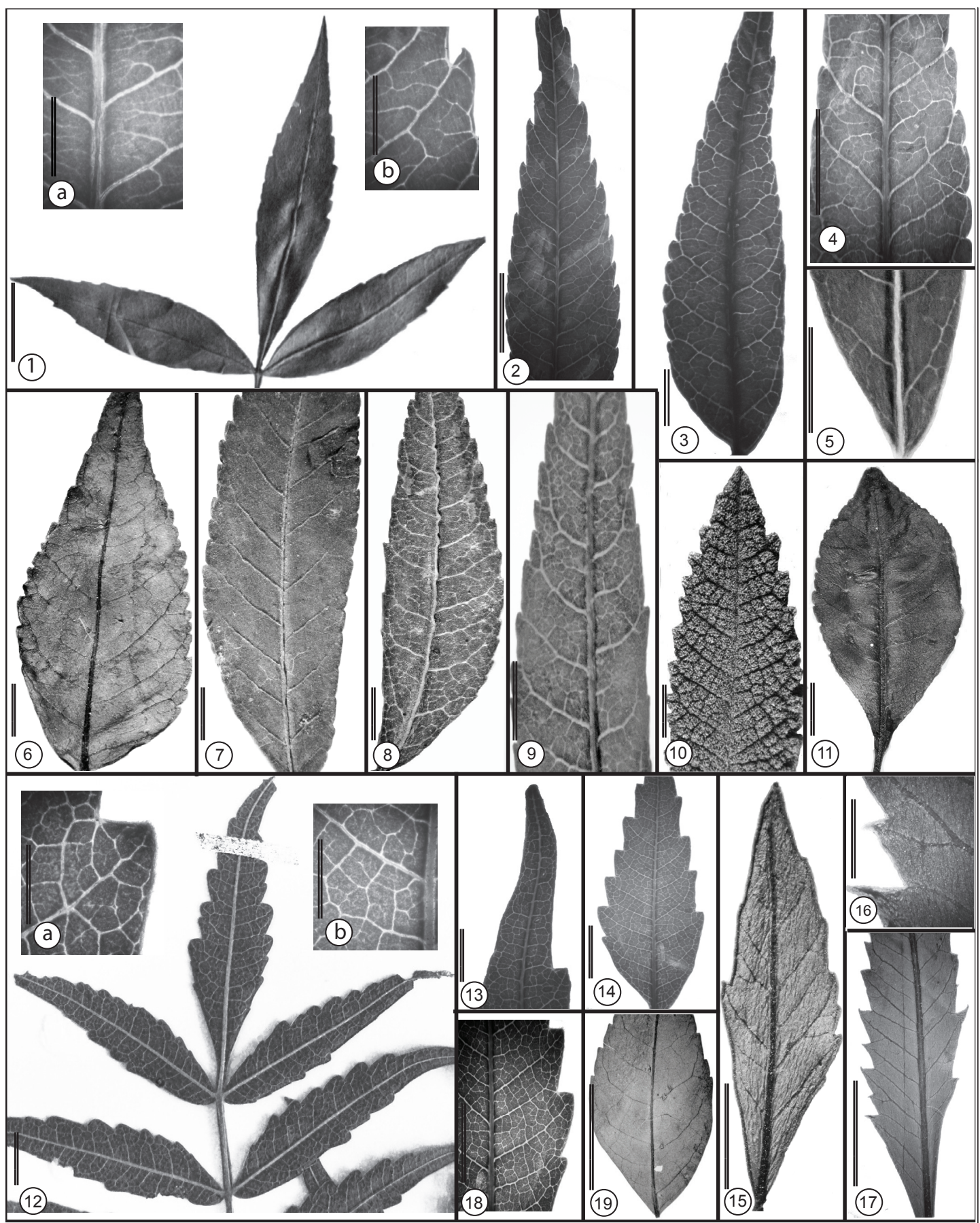

Fig. 3, 1 - 19. Leaves of extant taxa. 1 - 14, 18 - 19. Bursera spp. 15 - 17 Pseudosmodingium andrieuxii (Baill.) Engl. 1. B. fragilis S. Watson, leaflet with acute apex, entire proximal margin and toothed distally. Scale $=0.4 \mathrm{~mm}$. 1a. Closeup of tertiary venation. Scale $=0.2 \mathrm{~mm}, 1 \mathrm{~b}$. Secondary venation and teeth. Scale $=0.2 \mathrm{~mm}$. 2. B. fragilis, serrate margin and ovate lamina. Scale $=4 \mathrm{~mm} .3$. B. multijuga Engl., leaflet with asymmetric base, and cladodromous venation. Scale $=0.5 \mathrm{~mm}$. 4. B. multijuga, leaflet with cladodromous venation, straight $/$ straight teeth. Scale $=0.4 \mathrm{~mm}$. 5 . B. multijuga, cunneate base, dichotomizing tertiary veins. Scale $=0.3 \mathrm{~mm}$. 6. B. denticulate, McVaugh \& Rzed., asymmetric lamina with varied tooth morphology. Scale $=0.5 \mathrm{~mm}$. 7. $B$. denticulata, cladodromous venation with veins reaching the sinus, and smooth lamina in proximal zone. Scale $=0.5 \mathrm{~mm}$. 8,9 . B. lancifolia Engl., leaflet with asymmetric base, cladodromous venation and dichotomyzing tertiary veins. Scale $=0.5 \mathrm{~mm} .10$. B. cuneata Schlecht.) Engl, leaflet with fourth order venation forming regular reticulum. Scale $=0.5 \mathrm{~mm}$. 11. B. fagaroides $(\mathrm{HBK})$ Engl., leaflet with more than one order of teeth. Scale $=0.5$ $\mathrm{mm}$. 12. B. bonetii Rzedowski, leaflets comparing symmetric vs. asymmetric bases in terminal and lateral leaflets, and showing semicraspedodromous venation. Scale $=0.5 \mathrm{~mm} .12 \mathrm{a}$. Close up of tertiary vein inside teeth. Scale $=0.1 \mathrm{~mm}, 12 \mathrm{~b}$. Reticulate tertiary venation pattern. Scale $=0.1 \mathrm{~mm} .13 . B$. bonetii, leaflet apex with brochydodromous venation. Scale $=0.2 \mathrm{~mm} .14$. B. bonetii, leaflet with random reticulate fourth order venation. Scale $=0.5$ $\mathrm{mm}$. 15. P. andrieuxii, leaflet with straight apex and base, cladodromous venation, and variable tooth. $\mathrm{Scale}=0.5 \mathrm{~mm}$. 16 . P. andrieuxii, straight/straight teeth with cladodromous venation. Scale $=0.1 \mathrm{~mm} .17$. P. andrieuxii, leaflet with asymmetric lamina. Scale $=0.5 \mathrm{~mm} .18$. B. bonetii, reticulate venation pattern and tertiary vein running inside teeth. Scale $=10 \mathrm{~mm}$. 19. B. palaciosii Rzed. \& Calderon, leaflet with eucamptodromus venation, asymmetric rounded base. Scale $=0.8 \mathrm{~mm}$. 
complex and Caribbean species, and serrate/crenate margins as in the fossil material are more common. Furthermore, teeth in the fossil material are distributed in the distal $75 \%$ of the lamina, and the lamina has at least a small portion lacking teeth, as in many Bursera species. However, certain taxa like Commiphora and Canarium (Fig. 4.4-4.11) have leaflets similar to the fossil material, but leaflet shape (that tends to be oblong) and size of these two genera is different from those of the new Bursera species. Furthermore, their major secondary veins have mainly craspedodromous and eucamptodromous venation patterns along the whole lamina (Fig. 4.4-4.11), contrasting with the cladodromous, semi-craspedodromous and eucamptodromous patterns in the fossil material that may vary within the same lamina. Tertiary veins in these two extant genera are commonly mixed percurrent, contrasting with the reticulate pattern of $B$. popensis and B. ezequielii, as in some extant species of Bursera. Other differences with Canarium leaflets include a rounded base, and symmetrical lamina. Another genus, Crepidospermum, is similar to the fossil material in many characters, but it may be distinguished based on the festooning of the exterior tertiary veins and its larger leaflets.

Further comparison with other members of the family Burseraceae suggests differences in leaflet morphology. For example, the highly variable base in Protium, which ranges from rounded to convex or truncated, contrasts with the cuneate or convex base of the fossils. Furthermore, Protium has alternate/opposite-percurrent tertiary veins, which contrast with the reticulate tertiary veins in the new fossil material. Tetragastris and Haplolobus also differ from the new material in having mainly symmetric base, entire margin, percurrent tertiary veins, and acuminate apex (Fig. 4.14). The presence of secondary veins departing from the midvein at almost right angles distinguishes Trattinnickia from the new Bursera material; however, they also differ in the frequent percurrent arrangement of the tertiary veins. Boswellia differs from the fossils under discussion in its eucamptodromous secondary venation and dentate or crenate margin. Dacryodes and Santiria differ from the new material in having brochidodromous secondary venation, entire margin and acuminate apex, plus Santiria also has looped external tertiary veins.

The new fossil material is more similar to Bursera (Daly et al., 2011), where two sections are recognized. It has been stated that in general, section Bursera (Simaruba, Microphylla, Fagaroides and Fragilis groups) has dentate leaflets. However, within this section the Simaruba group seems to be the only one with entire margins (Becerra and Venable, 1999, p. 1053), though more recently the Caribbean species have been reported to have entire margin too (Rosell et al., 2010). The Fragilis group has been characterized based on its serrate or crenate leaflet margins, while only some taxa of the Fagaroides and Microphylla groups present entire margin (Becerra and Venable, 1999, p. 1053). Other observations based on leaf venation patterns (Andrés-Hernández, 1977, 2001; Rzedowski and
Kruse, 1979; Daly, 1993) confirm observations by Hickey and Wolfe (1975) and Daly et al. (2011) that while the brochidodromous pattern is common in Burseraceae, other patterns including eucamptodromous, cladodromous and semi-craspedodromous are also frequent.

In Bursera popensis the most common secondary venation pattern is semi-craspedodromous, but it also has some cladodromous veins (Fig. 2.1). In contrast, $B$. ezequielii has an eucamptodromous pattern in a leaflet along $75 \%$ of its lamina (Fig. 2.5), while in other leaflets venation is both eucamptodromous and cladodromous in the basal $25 \%$ of the lamina (Fig. 2.4). Identifying the type of secondary venation is difficult in $B$. ezequielii, since at first glance secondary veins seem to form loops interpreted as a brochidodromous pattern, as in Commiphora (Figs. 4.74.8, 4.10; also see Andrés-Hernández, 2001); however, in most cases the loop is formed due to the fusion of adjacent secondaries through a third order vein, giving rise to an eucamptodromous pattern (Figs. 3.12-3.14, 3.19, 4.2, 4.5, $4.9,4.12-4.13$ ). Other patterns that seem to be fairly constant in the family are also based on ramifying secondaries. If they ramify freely, that results in the cladodromous pattern (Figs. 3.1-3.2, 3.4, 3.10, 4.1, 4.4). However, if one of the branches reaches the sinus of a tooth, while the other joins the superjacent secondary forming a loop, the pattern would be semi-craspedodromous (Fig. 3.19; Fig. 4.5). These four patterns can be found mixed in the same leaf and leaflet.

The leaflet margin in B. popensis is serrate toward the apex of the leaflet, and entire near the base (Figs. 2.1, 2.3-2.5). Apparently, a similar situation is present in $B$. ezequielii, where the base of one of the leaflets appears crenate (Fig. 2.1, 2.3-2.5). Leaflets in extant Burseraceae have been described as serrate, dentate or crenate, but in many cases these characters do not apply to the whole leaf or leaflet (Fig. 3.1, 3.5-3.8, 3.11-3.12, 3.14, 3.19), and their distribution also varies. In some cases, the proximal leaf/ leaflet zone tends to be entire, while towards the distal zone the leaf/leaflet becomes serrate, dentate or crenate; in others, one side is serrate, dentate or crenate while the other is entire. It is also important to recognize that the tooth order, form, space between teeth, and number of teeth/cm vary (Figs. 3.1-3.19, 4.1-4.5). Tooth shape may change from convex/convex (Figs. 3.12, 3.12a) to straight/convex and straight/straight (Fig. 3.1, 3.1b, 3.2-3.4).

Affinity with Burseraceae is further supported by the combination of characters such as nanophyll leaflet size, elliptic outline, asymmetrical base, serrate/crenate margin, pinnate primary venation, third order venation producing a random reticulum, and entering the tooth, fourth order venation forming areoles and fifth and sixth orders dichotomizing giving place to free ending veinlets. Third order venation in extant Burseraceae is mainly ramified (Fig. 3.1a, 3.6-3.9), though reticulate has also been reported (Daly et al., 2011), and a percurrent pattern may also be observed (Figs. 3.6-3.13, 4.3, 4.6-4.7). These veins do not fill the intercostal lamina space, but tertiary veins actually 


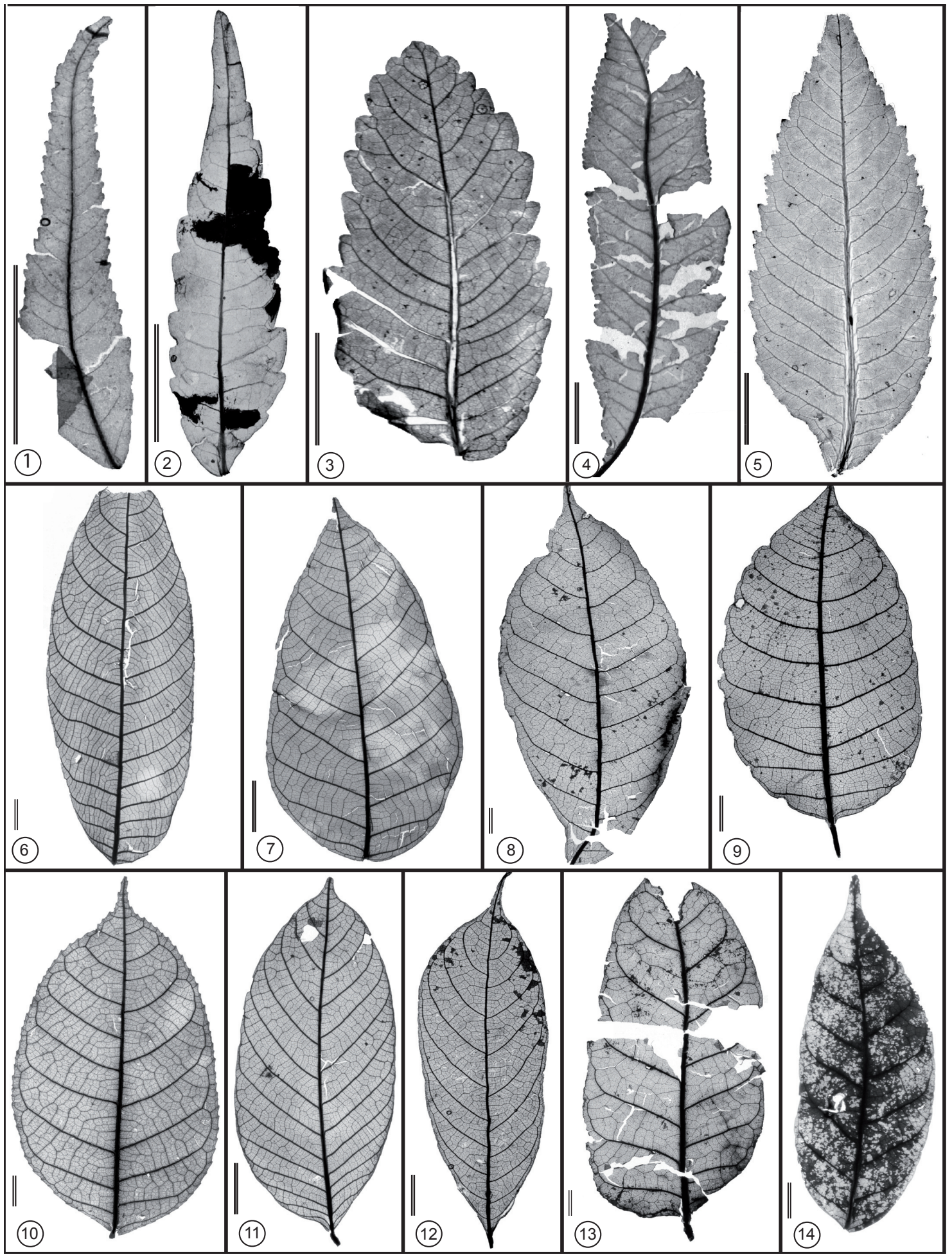

Fig. 4, 1- 14. Cleared leaves of extant Burseraceae. 1 - 4. Bursera spp., 5, 10. Commiphora, 6-9, 11-13 Canarium spp. 14. Haplolobus. 1. B. multijuga, leaflet showing veins reaching sinus. Scale $=1.00 \mathrm{~cm} .2$. B. bonetii, leaflet with asymmetric base, acute apex, and variable tooth form. Scale $=1.00 \mathrm{~cm}$. 3. B. submoniliformis Engl., leaflet with variable tooth form, cladodromous secondary venation, and tertiary percurrent venation. Scale $=1.00 \mathrm{~cm}$. $4 . B$. trimera Bullock, leaflet with cladodromous venation, and numerous small teeth. Scale $=1.00 \mathrm{~cm}$. 5. C. kyimbelensis Engl., leaflet with eucamptodromous venation. Scale $=1.00 \mathrm{~cm}$. 6. C. clementis Merr., leaflet with entire margin, tertiary percurrent venation. $\mathrm{Scale}=1.00 \mathrm{~cm} .7$. C. denticulatum Blume, leaflet with entire margin, brochidodromous venation, and tertiary percurrent venation. Scale $=1.00 \mathrm{~cm}$. 8. C. fissistipulum Miq., leaflet with elliptical lamina, entire margin and brochidodromous venation. Scale $=1.00 \mathrm{~cm}$. 9. C. harveyi Seem., leaflet with entire margin and eucamptodromous venation. Scale $=$ $1.00 \mathrm{~cm}$. 10. C. litorale Blume, leaflet with brochidodromous venation and toothed margin. Scale $=1.00 \mathrm{~cm} .11$. C. luxurians Engl., leaflet with oblong lamina and entire margin. Scale $=1.00 \mathrm{~cm} .12$. C. merilii, leaflet with eucamptodromous venation and tertiary venation random reticulate. Scale $=1.00$ $\mathrm{cm}$. 13. C. bitiensi, leaflet with asymmetric base, eucamptodromous venation, tertiary veins form a random reticulum. Scale $=1.00 \mathrm{~cm}$. 14 . H. floribundus (K. Schum.) H.J. Lam., leaflet with rounded asymmetrical base, semi-craspedodromous venation, entire margin. Scale $=1.00 \mathrm{~cm}$. 
reach the teeth. Fourth order venation forms either a regular (Fig. 3.10) or random (Fig. 3.8, 3.12b, 3.18) reticulum and forms the areoles that include veinlets that dichotomize to form fifth and sixth order veins. Surprisingly, this variable nature of the characters along the lamina is a key in the taxonomic determination of the family.

A more complete revision and description of the leaf/ leaflet architecture of Burseraceae is needed to fully understand the patterns; our own observations certainly suggest that the presence of two species of Bursera in the Eocene material from La Popa, Nuevo León, is well supported. Bursera popensis has characters that resemble those of the Fragilis group (e.g., B. fragilis and B. multijuga, Figs. 3.1-3.5) of section Bursera. It has narrow ellipticoblong, asymmetric lamina, serrate margin, straight apex, cuneate-convex base, semi-craspedodromous and cladodromous veins, angular sinus shape, and lamina divided into an entire region (basal $25 \%$ of lamina) and a serrate one (distal $75 \%$ of lamina). In contrast, B. ezequielii resembles members of section Bullockia, especially $B$. bonetii (Fig. 3.12, 3.12a, 3.12b-3.14, 3.18), in having sessile leaflets, elliptic-ovate lamina, serrate/crenate margins, eucamptodromous and cladodromous primary venation, random reticulate tertiary venation, convex/convex teeth, and well-developed areoles with dendritic veinlets.

The presence of Bursera in the fossil record is not new, but the interpretation of the environment where the fossil plants grew contrasts with their ecological affinities today (Reid and Chandler, 1933; Gregor and Goth, 1979). At least two other reports from North America are known where leaf/leaflets suggest the presence of this taxon (Reid and Chandler, 1933; Gregor and Goth, 1979). The oldest one, $B$. inaequilateralis (section Bullockia) from the Eocene Green River Formation, and a younger one, B. serrulata (section Bursera) from the Oligocene Florissant Beds, suggest that the genus formed part of different vegetation types (Manchester and Crane, 1983; Manchester et al., 1986; Boucher et al., 2003; Leopold et al., 2005; Meyer and Smith, 2005). Fruits from Eocene and Oligocene sediments of Europe further confirm the presence of Bursera and Canarium in communities that do not necessarily correspond with those in which the extant members of the genus grow (Reid and Chandler, 1933; Gregor and Goth, 1979). Other probable records, including pollen, have been discussed based on Cretaceous and more recent fossils (Harley et al., 2005; Graham, 2010, 2011).

Based on the distribution of extant Bursera, a taxon that today is an important element of seasonal dry tropical vegetation, its presence in La Carroza Formation may represent the oldest evidence of this type of vegetation, or the vegetation type where it differentiated. None of the floras studied so far has elements that would constitute by themselves an index of seasonally dry tropical vegetation. Dry conditions at the site where the Bursera popensis and $B$. ezequielii grew during the Eocene are further suggested by the presence of taxa like Inga, Senna, Chamaechrista
(Leguminosaea) and members of Anacardiaceae like Lanea (Calvillo-Canadell and Cevallos-Ferriz, 2005; RodríguezReyes, 2009). Pedological studies further suggest that the soils where the vegetation grew indicate high temperature and water stress (Lawton and Buck, pers. comm., 2007). In Mexico, the dry tropical vegetation has been well documented from Oligocene sediments onward (MagallónPuebla and Cevallos-Ferriz 1994a, 1994b; Velasco de León et al., 1998; Calvillo-Canadell and Cevallos-Ferriz, 2002), but the presence of dry tropical vegetation in those cases has been assumed based on leaf physiognomy, association of taxa and/or estimation of climatic parameters through CLAMP (Climate Leaf Analysis Multivariate Program), (Magallón-Puebla and Cevallos-Ferriz 1994a, 1994b; Velasco de León et al., 1998; Calvillo-Canadell and Cevallos-Ferriz, 2002).

While there is much to learn about the elements that composed La Popa flora, the general size of the leaves is larger than that observed in the Oligocene floras, interpreted as representing dry tropical vegetation in central Mexico (Magallón-Puebla and Cevallos-Ferriz 1994a, 1994b; Velasco de León et al., 1998; Calvillo-Canadell and Cevallos-Ferriz, 2002). On the other hand, leaves of the wet tropical Cretaceous localities are much larger, for example, those of the Olmos Formation, Coahuila (Weber, 1973, 1979; Estrada-Ruiz and Cevallos Ferriz, 2009; Estrada-Ruiz et al., 2011). Presence of drip-tips in some leaf types of $\mathrm{La}$ Popa would further suggest that this Eocene vegetation derives from a wet tropical one. Recent observations suggest that in this Eocene basin fossils represent two distinct vegetation sources: one with larger leaves and entire margin preserved in siltstone, and a second one with different types of leaflets preserved in medium sized sandstones and ashes. A final decision will need further observation of La Popa flora compared with that of other regions.

Presence of nearby wet and dry forests is common in many areas today, as for example, the Andes, or more dramatically in the Lesser Antilles, where the leeward and windward sides of a mountain have contrasting rainfall and vegetation types. The intricate, and continued tectonic activity that characterized Mexico during Cenozoic, can explain the source of forces that promoted selection and development of both types of vegetation. The plant assemblage collected at La Popa in northeastern Mexico, may be due to a process that impoverished the wet tropical Cretaceous floras, either along the Mexico/USA border floras, supporting the hypothesis that explains the dry tropical forest as a depauperate wet tropical forest (Graham and Dilcher, 1995; Pennington et al., 2009; Simon et al., 2009; Wing et al., 2009; Werneck et al., 2010), or alternatively, it may represent the expansion of dry floras of the eastern coast of the USA. In both cases, wet and dry floras may coexist. Under this geobiological scenery, the expansion of dry tropical vegetation in Mexico may follow the affectation of physiography through time, resulting in the establishment of windward and leeward conditions 
along the East coast (compare with Becerra, 2005; De Nova et al. 2012).

\section{Acknowledgements}

The authors recognize funding for this research from the Consejo Nacional de Ciencia y Tecnología, (CONACYT) projects 104515 to LCC and 82433 to SRSCF, as well as a scholarship to OJRR, and the Programa de Apoyo a Proyectos de Investigación e Innovación Tecnológica (PAPIIT)- UNAM 219810 to SRSCF. The discussion of our observation was enriched through comments of Dr. Jerzy Rzedowski, Instituto de Ecología, A.C., Pátzcuaro, Michoacán, México; and Dr. Douglas C. Daly, New York Botanical Garden, Bronx, NY USA. English (spelling and edition) was generously assisted by Dr. Ruth A. Stockey, University of Colorado at Boulder, and Dr. Alan Graham, Missouri Botanical Gardens.

\section{References}

Alroy, J., Kosnik, M., Peters, S., 2004, Palaeontology Databse Website: $<$ http://Paleodb.Org/Cgi-Bin/Bridge.Pl?A=Displaypage\&Page=Pe rsonnel>, consulted on november 22, 2008.

Andrés-Hernández, A.R., 1977, Análisis morfológico en plántulas de 11 especies del género Bursera Jacq. Ex L.: México, Facultad de Estudios Superiores Zaragoza, Universidad Nacional Autónoma de México, tesis de licenciatura, $52 \mathrm{p}$.

Andrés-Hernández, A.R., 2001, Análisis y descripción de estructuras foliares de especies del género Bursera Jacq. Ex L. que se distribuyen en la Cuenca del Río Balsas, México: México, Facultad de Ciencias, Universidad Nacional Autónoma de México, tesis de maestría, $86 \mathrm{p}$.

Andrie, J.R., Giles, K.A., Lawton, T.F., 2010, Halokinetic sequence stratigraphy and structural geometry of the Eocene fluvial Carroza Formation along the La Popa Salt Weld, La Popa Basin, Mexico, in Geological Society of London-Society of Economic Paleontologists and Mineralogists Conference - Salt Tectonics, Sedimentation, and Prospectivity: London, United Kingdom, Burlington House, London, p. 66.

Antonelli, A., Sanmartín. I., 2011, Why are so many plant species in the tropics?: Taxon, 60(2), 403-414.

Antonelli, A., Nylander J.A.A., Persson, C. Sanmartín, I., 2009, Tracing the impact of the Andean uplift on Neotropical plant evolution: Proceedings of the National Academy of Science, United States of America, 106, 9749-9754.

Bartish, I.V., Antonelli, A., Richardson, J.E. Swenson, U., 2011, Vicariance or long-distance dispersal: historical biogeography of the pantropical subfamily Chrysophylloideae (Sapotaceae): Journal of Biogeography, 38(1), 177-190.

Becerra, J.X., 2003, Synchronous coadaptation in an ancient case of herbivory: Proceedings of the National Academy of Science, United States of America, 100, 12804-12807.

Becerra, J.X., 2005, Timing the origin and expansion of the Mexican tropical dry forests: Proceedings of the National Academy of Science, United States of America, 102, 10919-23.

Becerra, J.X., Venable. L., 1999, Nuclear ribosomal DNA phylogeny and its implications for evolutionary trends in Mexican Bursera (Burseraceae): American Journal of Botany, 86, 1047-1057.

Boucher, L.D., Manchester, S.R., Judd, W.S., 2003, An extinct genus of Salicaceae based on twigs with attached flowers, fruits, and foliage from the Eocene Green River Formation of Utah and Colorado,
USA: American Journal of Botany, 90, 1389-1399.

Burnham, R.J., Johnson, K.R., 2004, South American paleobotany and the origins of neotropical rainforests: Philosophical Transactions of the Royal Society of London, series B, 359, 1595-1610.

Calvillo-Canadell, L., Cevallos-Ferriz. S.R.S., 2002, Bauhcis moranii gen. et sp. nov. (Cercideae, Caesalpinieae) an Oligocene plant from Tepexi de Rodríguez, Puebla, Mex., with leaf architecture similar to Bauhinia and Cercis: Review of Palaeobotany and Palynology, 122(3-4), 171-184.

Calvillo-Canadell, L., Cevallos-Ferriz. S.R.S., 2005, Diverse assemblage of Eocene and Oligocene Leguminosae from Mexico: International Journal of Plant Science, 166(4), 671-692.

Calvillo-Canadell, L., Cevallos-Ferriz. S.R.S., 2007, Flowers of Rhamnaceae from the Cerro del Pueblo (Upper Cretaceous, Coahuila) and Coatzingo (Oligocene, Puebla) Formations, Mexico: American Journal of Botany, 94(10), 1658-1669.

Calvillo-Canadell, L., Cevallos-Ferriz. S.R.S., Rico-Arce, L., 2010, Legume flowers preserved in amber from Simojovel de Allende Chiapas, Mexico: Review of Palaeobotany and Palynology, 160, 126-134.

Camacho-Rico, F., Trejo, I. Bonfil, C., 2006, Estructura y composición de la vegetación ribereña de la barranca del río Tembembe, Morelos, México: Boletín de la Sociedad Botánica de México, 78, 17-31.

Castañeda-Posadas, C., Cevallos-Ferriz, S.R.S., 2007, Swietenia (Meliaceae) flower included in Miocene amber from Simojovel de Allende, Chiapas, Mexico: American Journal of Botany, 94(11), 1821-1827.

Cerros-Tlatilpa, R., Espejo-Serna, A., 1998, Contribución al estudio florístico de los Cerros El Sombrerito y Las Mariposas (Zoapapalotl) en los municipios de Tlayacapan, Morelos, México: Polibotánica, 8, 29-46.

Cervantes-Duarte, R., Aguirre-Bahena, F., Reyes-Salinas, A., ValdezHolguín, J.E., 2001, Caracterización hidrológica de una laguna costera de Baja California Sur, México: Oceánides, 16(2), 93-105.

Cevallos-Ferriz, S.R.S., González-Torres, E.A., 2006, Geological setting and phytodiversity in Mexico, in Vega, F.J., Nyborg, T.G., Perrilliat, M.C., Montellano, M., Cevallos-Ferriz, S.R.S., Quiroz, S., (eds.), Studies on Mexican Paleontology: The Netherlands, Springer, 1-15.

Daly, D.C., 1993, Notes on Bursera in South America including a new species: Studies in Neotropical Burseraceae VII, Brittonia, 45, 240-246.

Daly, D.C., 1997, Burseraceae, in Steyermark, J.A., Berry, P.E., Holst, B.K. (eds.), Flora of the Venezuelan Guayana: Missouri Botanical Garden, 3, 688-728.

Daly, D.C., Martínez-Habibe, M.C., Weeks, A., Harley, M.M., 2011, Burseraceae, in Kubitzki, K. (ed.), The families and genera of vascular plants: New York, Springer-Verlag, 76- 104.

De Nova, J.A., Medina, R., Montero, J.C., Weeks, A., Rosell, J., Olson, M.E., Eguiarte, L.E., Magallón. S., 2012, Insights into the historical construction of species-rich Mesoamerican seasonally dry topical forest: the diversification of Bursera (Burseraceae, Sapindales): New Phytologist, 193, 276-287.

Duncan, T., Meacham, C.A., 1986, Multiple-entry keys for the identification of angiosperm families using a microcomputer: Taxon, 35, 492-494.

Ellis, B., Daly, D.C., Hickey, L.J., Johnson, K.R., Mitchell, J.D., Wilf, P., Wing, S., 2009, Manual of Leaf Architecture: New York, Comstock Publishing Associates and The New York Botanical Garden, $67 \mathrm{p}$.

Estrada-Ruiz, E., Cevallos-Ferriz. S.R.S., 2009, Palmoxylon enochi sp. nov. de la Formación Olmos (Campaniano superior-Maastrichtiano inferior), Coahuila, México: Ameghiniana, 46(4), 577-585.

Estrada-Ruiz, E., Upchurch, G.R., Cevallos-Ferriz, S.R.S., 2008, Flora and climate of the Olmos Formation (Upper Campanian-Lower Maastrichtian), Coahuila, Mexico: a preliminary report: Gulf Coast Association of Geological Societies Transactions, 58, 273-283.

Estrada-Ruiz, E., Upchurch Jr., G.R., Wolfe, J.A., Cevallos-Ferriz, S.R.S., 2011, Comparative morphology of fossil and extant leaves of Nelumbonaceae, including a new genus from the Late Cretaceous of Western North America: Systematic Botany, 36, 337-351. 
Gentry, A., 1995, Diversity and floristic composition of neotropical dry forests, in Bullock, S H., Mooney, H.A., Medina, E., (eds.), Seasonally dry tropical forests: Cambridge, United Kingdom, Cambridge University Press, 146-194.

Givnish, T.J., 1979, On the adaptive significance of leaf form. Topics, in Solbrig, O.T., Jain, S., Johnson, G.B., Raven, P.H., (eds.): Plant Population Biology: New York, Columbia University Press, 375-407.

Graham, A., 1999, The Tertiary history of the northern temperate element in the northern Latin American biota: American Journal of Botany, 86(1), 32-38

Graham, A., 2010, Late Cretaceous and Cenozoic history of Latin American vegetation and terrestrial environments: Missouri Botanical Garden Press, $617 \mathrm{p}$.

Graham, A., 2011, Catalog and literature guide for Cretaceous and Cenozoic vascular plants of the New World: <http://www.mobot. org $/$ mobot/research/CatalogFossil/catalog/shtml $>$.

Graham, A., Dilcher, D.L., 1995, The Cenozoic record of tropical dry forest in northern Latin America and the southern United Status, in Bullock, S.H., Mooney, H.A., Medina, E., (eds.), Seasonally dry tropical forests: Cambridge, United Kingdom, Cambridge University Press, 124-145.

Gregor, V.J., Goth, K., 1979, Erster Nachweis der Gattung Canarium Stickman 1759 (Burseraceae) im europaischen Alttertiar: Stuttgarter Beiträge zur Naturkunde, Serie B (Geologie und Paläontologie), $47,1-15$.

Harley, M.M., Song, U., Banks, H.I., 2005, Pollen morphology and systematics of Burseraceae: Grana, 44(4), 282-299.

Hickey, L.J., Wolfe, J.A., 1975, The bases of angiosperm phylogeny: vegetative morphology: Annals of the Missouri Botanical Garden, 62, 538-589.

Leopold, E.B., Manchester, S.R., Meyer, H.W., 2005, Phytogeography of the late Eocene Florissant flora reconsidered, in Meyer, H.W. Smith, D.M., (eds.), Paleontology of the Upper Eocene Florissant Formation, Colorado: Geological Society of America Special Paper, 435, 53-70.

Magallón-Puebla, S., Cevallos-Ferriz, S.R.S., 1994a, Eucommia constans n. sp. fruits from the upper Cenozoic strata of Puebla Mexico: morphological and anatomical comparison with Eucommia ulmoides Oliver: International Journal of Plant Sciences, 155, 80-95.

Magallón-Puebla, S., Cevallos-Ferriz, S.R.S., 1994b, Latest occurrence of the extinct genus Cedrelospermum (Ulmaceae) in America: Cedrelospermum manchesteri sp. nov. from the upper Cenozoic of Puebla, México: Review of Palaeobotany and Palynology, 81, 115-128.

Manchester, S.R., Crane, P.R., 1983, Attached leaves, inflorescences, and fruits of Fagopsis, an extinct genus of fagaceous affinity from the Oligocene Florissant Flora of Colorado, United States of America: American Journal of Botany, 70, 1147-1164.

Manchester, S.R., Dilcher, D.L., Tidwell, W.D., 1986, Interconnected reproductive and vegetative remains of Populus (Salicaceae) from the Middle Eocene Green River Formation, northeastern Utah: American Journal of Botany, 73, 156-160.

Martínez-Cabrera, H.I., Cevallos-Ferriz, S.R.S., 2008, Palaecology of the Miocene El Cien Formation (Mexico) as determined from wood anatomical characters: Review of Palaeobotany and Palynology, 150, 154-167.

Martínez-Millán, M., Cevallos-Ferriz, S.R.S., 2005, Arquitectura foliar de Anacardiaceae: Revista Méxicana de Biodiversidad, 76(2), 137-190.

Martínez-Yrízar, A., Búrquez, M.A., Maass, M., 2000, Structure and functioning of tropical deciduous forest in western Mexico, in Robichaux, R.H., Yetman, D., (eds.), The tropical deciduous forest of Alamos: biodiversity of a threatened ecosystem in Mexico: Tucson, Arizona, United States of America, University of Arizona Press, 19-35.

McBride, E.F., Weidie, A.E., Wolleben, J.A., Laudon, R.C., 1974, Stratigraphy and structure of the Parras and La Popa basins, northeastern Mexico: Geological Society of America Bulletin, 85, $1603-1622$

Metcalfe, C.R., Chalk, L., 1950, Anatomy of the Dicotyledons, Vol. 2:
Oxford, United Kingdom, Clarendon Press, 297 p.

Meyer, H.W., Smith, D.M., (eds.), 2005, Paleontology of the Upper Eocene Florissant Formation, Geological Society of America Special Paper 435, 1-177.

Miranda, F., Hernández-X., E., 1963, Los tipos de vegetación en México y su clasificación: Boletín de la Sociedad Botánica de México, 28, 29-179.

Mooney, H.A., Bullock, S.H., Medina, E., 1995, Introduction, in Bullock, S.H., Mooney, H.A., Medina, E., (eds.), Seasonally dry tropical forests: Cambridge, United Kingdom, Cambridge University Press, 1-8.

Murphy, P., Lugo, A.E., 1986, Ecology of tropical dry forest: Annual Review of Ecology, Evolution, and Systematics, 17, 67-88.

Pennington, R.T., Prado, D.E., Pendry, C.A., 2000, Neotropical seasonally dry forests and Pleistocene vegetation changes: Journal of Biogeography, 27, 261-273.

Pennington, R.T., Lavin, M., Prado, D.E., Pendry, C.A., Pell, S.K., Butterworth, C.A., 2004, Historical climate change and speciation: Neotropical seasonally dry forest plants show patterns of both Tertiary and Quaternary diversification: Philosophical Transactions of the Royal Society London, Series B, Biological Sciences, 359, $515-537$.

Pennington, R.T., Ratter, J.A., Lewis, G.P., (eds.), 2006a, Neotropical savannas and seasonally dry forests: Plant Biodiversity, Biogeography and Conservation: Boca Raton, Florida, CRC Press, $447 \mathrm{p}$.

Pennington, R.T., Ratter, J.A., Lewis, G.P., 2006b, An overview of the plant diversity, biogeography and conservation of neotropical savannas and seasonally dry forests, in Pennington, R.T., Lewis, G.P. Ratter, J.A., (eds.), Neotropical savannas and seasonally dry forests: Plant diversity, biogeography and conservation: Boca Raton, Florida, CRC Press, 1-29.

Pennington R.T., Richardson, J.A., Lavin, M., 2006c, Insights into the historical construction of species-rich biomes from dated plant phylogenies, phylogenetic community structure and neutral ecological theory: New Phytologyst, 172, 605-616.

Pennington, R.T., Lavin, M., Oliveira-Filho, A., 2009, Woody plant diversity, evolution, and ecology in the Tropics: Perspectives from seasonally dry tropical forests: Annual Review of Ecology, Evolution, and Systematics, 40, 437-457.

Peralta-Medina, E., 2009, Arquitectura foliar de hojas fósiles de Ixtapa, Chiapas, México: Mexico, Facultad de Ciencias, Universidad Nacional Autónoma de México, tesis de licenciatura, $77 \mathrm{p}$.

Perrilliat, M.C., Vega, F.J., 2003, Lower Eocene large ostreids from the Viento Formation; a stratigraphic and paleoecologic contribution to La Popa Basin, Nuevo León, Mexico: American Association of Petroleum Geologists Memoir, 79, 419-426.

Perrilliat, M.C., Vega, F.J., Espinosa, B., Naranjo-García, E., 2008, Late Cretaceous and Paleogene freshwater Gastropods from northeastern Mexico: Journal of Paleontology, 82, 255-266.

Ramírez-Garduño, J.L., Cevallos-Ferriz, S.R.S., 2000, Leaves of Salicaceae (Salix and Populus) from Oligocene sediments, near Tepexi de Rodríguez, Puebla: International Journal of Plant Sciences, 161(3), 521-534.

Reid, E.M., Chandler, M.E.J., 1933, The London Clay Flora: London, British Museum (Natural History), 561p.

Rodríguez-Reyes, O.J., 2009, Material foliar del Eoceno del la Formación Carroza en La Popa, Nuevo León, México: México, D.F., Posgrado en Ciencias Biológicas, Universidad Nacional Autónoma de México, tesis de maestría, $79 \mathrm{p}$.

Rosell, J.A., Olson, M.E., Weeks, A., De Nova, J.A., Medina-Lemos, R., Pérez-Camacho, J., Feria, T.P., Gómez-Bermejo, R., Montero, J.C., Eguiarte. L.E., 2010, Diversification in species complexes: Tests of species origin and delimitation in the Bursera simaruba clade of tropical trees (Burseraceae): Molecular Phylogenetics and Evolution, 57, 798-811.

Rundel, P.W., Boonpragob, K., 1995, Dry forest ecosystems of Thailand, in Bullock, S.H., Mooney, H.A., Medina, E., (eds.), Seasonally dry tropical forests: Cambridge, United Kingdom, Cambridge University Press, 93-123. 
Rzedowski, J., Kruse, H., 1979, Algunas tendencias evolutivas en Bursera (Burseraceae): Taxon, 28,103-116.

Schrire, B.D., Lavin, M., Lewis, G.P., 2005a, Global distribution patterns of the Leguminosae: insights from recent phylogenies, in Friis, I., Balslev, H., (eds.), Plant diversity and complexity patterns: local, regional and global dimensions: Biologiske Skrifter, 55, 375-422.

Schrire, B.D., Lewis, G.P., Lavin, M., 2005b, Biogeography of the Leguminosae, in Lewis, G., Schrire, B., MacKinder, B., Lock, M., (eds.), Legumes of the World: Kew, United Kingdom, Royal Botanic Gardens, 21-54.

Schrire, B.D., Lavin, M., Barker, N.P., Forest, F., 2009, Phylogeny of the tribe Indigofereae (Leguminosae-Papilionoideae): Geographically structured more in succulent-rich and temperate settings than in grass-rich environments: American Journal of Botany, 96, 816-852.

Scotese, C.R., 2002, Climate History (Chart) (online): <www.scotese. com>; $<$ http://www.scotese.com/climate history.htm>, consulted on: 20 de abril de 2002.

Simon, M.F., Grether, R., de Queiroz, L.P., Skema, C., Pennington, R.T., Hughes, C.E., 2009, Recent assembly of the Cerrado, a neotropical plant diversity hotspot, by in situ evolution of adaptations to fire: Proceedings of the National Academy of Sciences of the United States of America, 106(48), 20359-64.

Soeegard, K.H., Kalik, Y.E., Daniels, A.T., Arney, J., Garrick, S., 2003, Stratigraphic evolution of the Latest Cretaceous to early Tertiary Difunta foreland basin in northeast Mexico: Influence of salt withdrawal on tectonically induced subsidence by the Sierra Madre Oriental fold and thrust belt, in Bartolini, C., Buffler, R.T., Blickwede, J. (eds.), The Circum-Gulf of Mexico and the Caribbean: Hydrocarbon habitats, basin formation, and plate tectonics: American Association of Petroleum Geologists Memoir, 79, 364-394.

Solereder, H., 1908, Systematic anatomy of the dicotyledons: Clarendon Press, Oxford University, United Kingdom, 834 p.

Trejo, I., 1996, Características del medio físico de la selva baja caducifolia en México, Investigaciones Geográficas: Boletín Instituto de Geografía, Número especial 4, 95-110.
Velasco de León, P., Cevallos-Ferriz, S.R.S., Silva-Pineda, A., 1998, Leaves of Karwinskia axamilpense n. sp. (Rhamnaceae) from Oligocene sediments, near Tepexi de Rodríguez, Puebla: Canadian Journal of Botany, 76, 410-419.

Watson, L., Dallwitz, M.J., 1992 onwards, The families of flowering plants: descriptions, illustrations, identification, and information retrieval: $<$ http://delta-intkey.com>, consulted on: 15 de mayo de 2010.

Weber, R., 1973, La vegetación maestrichtiana de la Formación Olmos de Coahuila, México: Boletín de la Sociedad Geológica Mexicana, 33, 5-19.

Weber, R., 1979, Some aspects of the Upper Cretaceous angiosperm flora of Coahuila, Mexico: Courier Forschungsinstitut Senckenberg, 30, 38-46.

Wendt, T., 1993, Composition floristic affinities and origins of the canopy tree flora of the Mexican Atlantic slope rain forests, in Ramamoorthy, T.P, Bye, R., Lot, A., Fa, J. (eds.), Biological diversity of Mexico, origins and distribution: New York, Oxford University Press, 595680.

Werneck, F.P., Costa, G.C., Colli, G.R., Prado, D.E., Sites Jr., J.W., 2010, Revisiting the historical distribution of seasonally dry tropical forests: new insights based on palaeodistribution modelling and palynological evidence: Global Ecology and Biogeography, 20, 272-288.

Willis, K.J., McElwain, J.C., 2002, The Evolution of Plants: United Kingdom, Oxford University Press, $378 \mathrm{p}$.

Wing, S.L., Herrera, F., Jaramillo, C.A., Gómez-Navarro, C., Wilf, P., Labandeira, C.C., 2009, Late Paleocene fossils from the Cerrejon Formation, Colombia, are the earliest record of Neotropical rainforest: Proceedings of the National Academy of Sciences of the United States of America, 106, 18627-32.

Manuscript received: May 6, 2013.

Corrected manuscript received: July 5, 2013.

Manuscript accepted: July 12, 2013. 